\title{
The Influence of Partial Surface Shot Peening on Fatigue Crack Growth Behaviour of a High Strength Ferritic Steel
}

\author{
Ali Al-Turaihi ${ }^{1}$, Ali Mehmanparast ${ }^{1}$, Feargal Brennan ${ }^{1}$, \\ ${ }^{1}$ Offshore Renewable Energy Engineering Centre, Cranfield University, Cranfield, Bedfordshire \\ MK43 0AL, UK
}

\begin{abstract}
The effects of partial surface shot peening on the fatigue crack growth behaviour of a ferritic steel have been experimentally investigated in this paper. Dog-bone specimens fabricated from Optim $700 Q L$ were tested under Tension-Tension fatigue loads. Three distinct extents of partial shot peening, with respect to the crack tip and specimen symmetry line, were tested. The fatigue crack growth results from these experiments have been compared with those obtained from the same specimen geometry but with no peening. The results show that the residual stress fields formed ahead of the initial notch tip due to the partial peening process play a significant role in the fatigue crack growth behaviour of the material and effectively result in accelerated crack propagation at the mid-width of the specimens. It has been shown in this study that partial peening can lead to a fatigue crack growth rate around twice as fast as that of the unpeened specimen.
\end{abstract}

Keywords: Fatigue, Torsion, Fatigue limit, Shot peening, High-strength steel, Surface defect, Residual stress

\section{Introduction}

Surface treatment is known to be an efficient technique to improve the fatigue life of engineering components and structures [1]. Shot peening is one of the mechanical surface treatment techniques used to create compressive residual stresses underneath the surface to reduce the effective local stresses and improve structural integrity and fatigue resistance in 
structures which are subjected to fatigue loading conditions such as offshore structures. Shot peening is performed by projecting small particles at high speed onto the surface of material, leading to a local plastic deformation on the surface. By using this technique a compressive residual stress field appears in the surrounding elastically deformed material [2][3]. Many studies were carried out in the past to investigate the effect of shot peening on crack initiation, propagation and fatigue strength in different materials. For example Donzella et al. have studied the effect of shot peening on mechanical properties, material micro-structure and residual stress profile in sintered steel plates [4]. In another independent study, Yang et al. created a nanostructured surface layer in H13 steel by shot peening and noticed that the high temperature wear resistance was improved as a result of peening, and enhanced fatigue crack initiation and propagation behaviour was observed in the nanostructured layer due to compressive residual stresses [5]. Gan et al. have investigated the effect of shot peening on a T-welded structure made of Q345D steel [6] and found that the suitable peening intensity could improve fatigue life compared with an unpeened structure. Pyttel et al. and Giannakis and Savaidis have calculated analytically fatigue strength based on the "Fracture Mechanics Proof of Strength for Engineering Components" (FKM) guideline for stress shot peened high strength leaf springs samples under a three-point bending fatigue test [7] [8] and found that the fatigue life was improved as a result of peening. Mahmoudi et al. studied the effect of initial compressive residual stress on subsequent compressive residual stress induced by shot peening, and found that the initial residual stress was wiped out by shot peening up to the maximum compressive residual stress point [9]. Yang et al. used finite element simulations to study the effect of the initial surface finish of the target, on shot peening effectiveness and found that the initial rough surface leads to a major reduction in the effectiveness of shot peening [10]. Takahashi et al. investigated the effect of shot peening on the torsional fatigue limit in specimens containing artificial defects in high strength steel specimens and found that the defect with specific dimensions could be rendered harmless by shot peening. Moreover, Klocke et al. proposed a feasible method for assessing the homogeneity of residual stress distribution on shot peened steel [11]. Akyildiz et al. have investigated the effect of shot peening parameters on fatigue strength of steel manufactured by powder metallurgy (PM). They found that the fatigue behaviour of this material improved by surface peening process and the best fatigue performance obtained with the specimens that were shot peened at 20 Almen intensity and $100 \%$ saturation [12]. Honda et al. have investigated the effect of shot peening on number of fatigue cycles to failure on 7075-T7351 single edge notch bend SEN(B) specimens and they found that while the residual stresses locally retarded the crack 
growth rate, they had no effect on the overall crack propagation trend [13]. Ishigami et al have studied the influence of stress double shot peening and stress reflection double shot peening methods to quenched and tempered steel and they found that the latter induced greater compressive residual stress at the outer surface of specimens [14]. Voorwald et al. have investigated the effect of shot peening on rotating bending fatigue strength of chromium electroplated AISI 4340 steel for landing gear applications and they found that the fatigue strength improved. They also showed that the peening process using ceramic shots resulted in lower scatter in rotating bending fatigue data than the steel shots [15]. You et al have studied the residual stress relaxation behaviour during low cycle fatigue tests on notched and flat shot peened specimens. They found out that shot peening was more effective in fatigue life enhancement of notched specimens by restricting the compressive residual stress relaxation during fatigue tests [16]. As the last example, Závodská et al. studied the effect of shot peening on fatigue strength in a low alloy steel and realised that there is an increasing positive effect on fatigue strength for crack initiation and growth as a result of shot peening [17].

A review of the past studies has revealed that shot peening effects on fatigue crack initiation and growth were examined by applying this surface treatment technique on the entire surface of the steel samples. However, the influence of partial peening on subsequent fatigue crack growth behaviour is yet to be investigated and compared to full surface treatment. In the present study, partial shot peening areas were introduced in 700OptimQL high strength steel specimens. The high strength steels provide advantages over conventional steels where the strength to weight ratio is important. High strength steels with yield strength ranging from 500 to $700 \mathrm{MPa}$ are being increasingly used in the offshore engineering industry, involving production jack-ups with demanding requirements [18]. In this paper, the shot peening extent was implemented at three different distances from the initial notch tip in dog-bone specimens to study the effect of partial shot peening on the fatigue crack growth and crack retardation behaviour of the material. The results from these tests are presented below and compared to the fatigue crack growth behaviour of the material in unpeened specimens. 


\section{Experimental details}

\subsection{Material and specimen design}

The material used in this study is Optim700 $Q L$ high strength steel. The mechanical properties and chemical composition of this material are summarised in Table 1. This material is used for offshore structures such Jack-ups \& Moorings due to its advantages over conventional steel where strength to weight ratio is high.

Table 1: Chemical composition and Mechanical properties of Optim700QL

\begin{tabular}{|c|c|}
\hline \multicolumn{2}{|c|}{ Chemical composition of 700 OptimQL } \\
\hline Element & WT\% \\
\hline $\mathrm{C}$ & 0.156 \\
\hline SI & 0.32 \\
\hline $\mathrm{MN}$ & 0.99 \\
\hline $\mathrm{P}$ & 0.009 \\
\hline $\mathrm{AL}$ & 0.047 \\
\hline NB & 0.002 \\
\hline $\mathrm{V}$ & 0.01 \\
\hline TI & 0.023 \\
\hline $\mathrm{CU}$ & 0.023 \\
\hline $\mathrm{CR}$ & 0.59 \\
\hline NI & 0.2 \\
\hline MO & 0.198 \\
\hline B & 0.0016 \\
\hline ZR & 0.002 \\
\hline \multicolumn{2}{|c|}{ Mechanical properties of $700 O p t i m Q L$} \\
\hline Ultimate Tensile Strength $(M P a)$ & 833 \\
\hline Yield Strength $(\mathrm{MPc}$ & 690 [19] \\
\hline
\end{tabular}

Dog-bone shaped test specimens were extracted from a $25 \mathrm{~m}$ thick plate in such a way that the loading axis was parallel to the rolling direction of the steel plate. Figure 1 illustrates the specimen geometry details as well as the initial notch details, which was introduced into the 
specimen using the Electrical Discharge Machining (EDM) method. The dog-bone specimen has been designed based on the ASTM E740 standard. As shown in Figure 1, the maximum width and length are $80 \mathrm{~mm}$ and $330 \mathrm{~mm}$ respectively, while the thickness and radius of curvature are $15 \mathrm{~mm}$ and $40 \mathrm{~mm}$ respectively. Three nominally identical specimens were machined and then subsequently subjected to partial shot peening to different extents, with respect to the initial notch tip. Table 2 shows the details and number of specimens used in this study.

Table 2: Test matrix

\begin{tabular}{|c|c|c|}
\hline Specimen name & Extent of the unpeened area, A & Number of specimens \\
\hline A60 & Without peening & 1 \\
\hline A10 & $10 \mathrm{~mm}$ & 1 \\
\hline A20 & $20 \mathrm{~mm}$ & 2 \\
\hline A30 & $30 \mathrm{~mm}$ & 1 \\
\hline
\end{tabular}

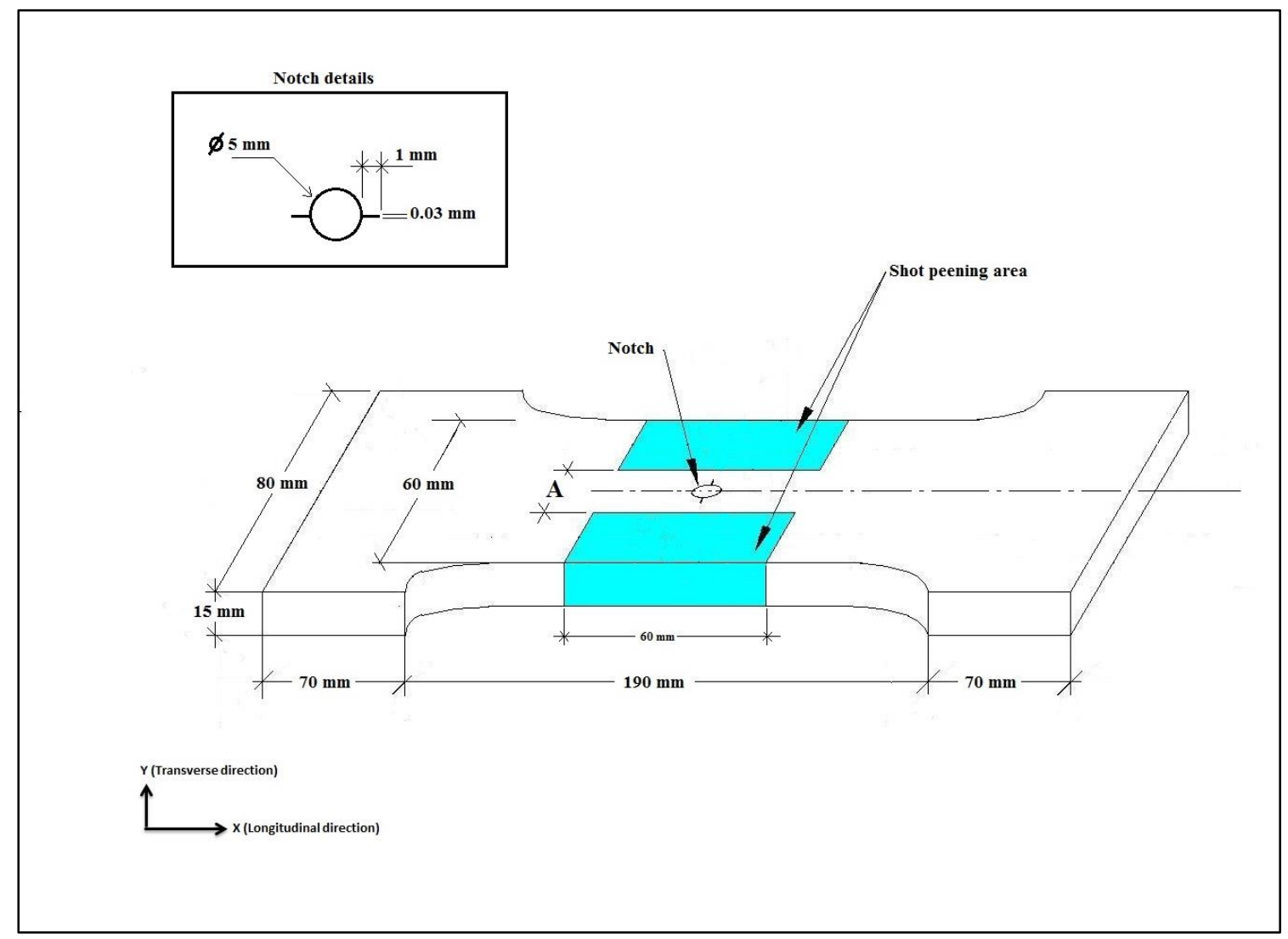

Figure 1: Test specimen and notch details 


\subsection{Numerical prediction of stress concentration factor}

The stress concentration factor (SCF) solutions for the geometry used in this study are not available in the literature. Therefore a finite element model was developed to work out the SCF solutions for the specimen design employed in this project. A full-scale model of the dog-bone shaped specimen geometry was constructed in the ABAQUS finite element software package (see Figure 2) with the notch on the middle length of the specimen to calculate SCF. The geometry was partitioned to obtain a finer mesh at the crack zone as shown in Figure 2. A structured mesh was used in simulations and the mesh was coarsened away from the notch tip region to reduce the computational power in finite element simulations [20]. The mesh structure employed in finite element simulations is shown in Figure 3. A standard element type has been used with a three dimensional 8-node brick solid element, C3D8. Eight different central hole diameter sizes, $D$, were examined in simulations to investigate the effect of hole diameter on dog-bone specimen SCF values. The local and global stresses for each hole diameter case was predicted using finite element simulations.. The SCF was subsequently calculated using Equation 1.

$$
S C F=\frac{\sigma_{\text {local }}}{\sigma_{\text {global }}}
$$

\section{Equation 1}

where, $\sigma_{\text {local }}$ is the maximum stress around the hole which is located around the central hole as shown in Figure 4 and $\sigma_{\text {global }}$ is the global stress applied on the geometry. A mesh convergence study was carried out for the geometry used in this study to find out the optimum number of elements around the hole. The mesh convergence was found at around 9 element/mm for the employed geometry as shown in Figure 5. The SCF values obtained from finite element simulations are plotted against $D$ the hole diameter normalised by $W$ the specimen width, $D / W$, and the results are shown in Figure 6. A second degree polynomial fit was made to develop a general solution for SCF as a function of $D / W$. The equation of the line of best fit made to the numerical data points is described in Equation 2. As seen in this equation, the SCF for the specimen geometry used in this study with D/W of 0.083 (see Figure 1) is 3.8 .

$$
S C F=0.1423\left(\frac{D}{W}\right)^{2}+2.6346\left(\frac{D}{W}\right)+3.5702
$$




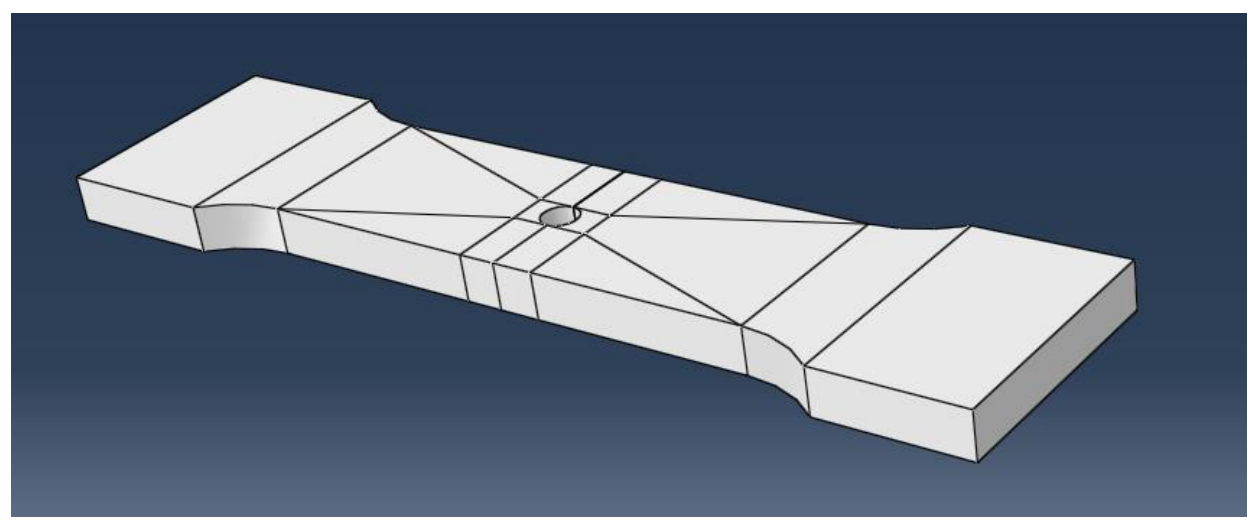

Figure 2: Specimen partitions

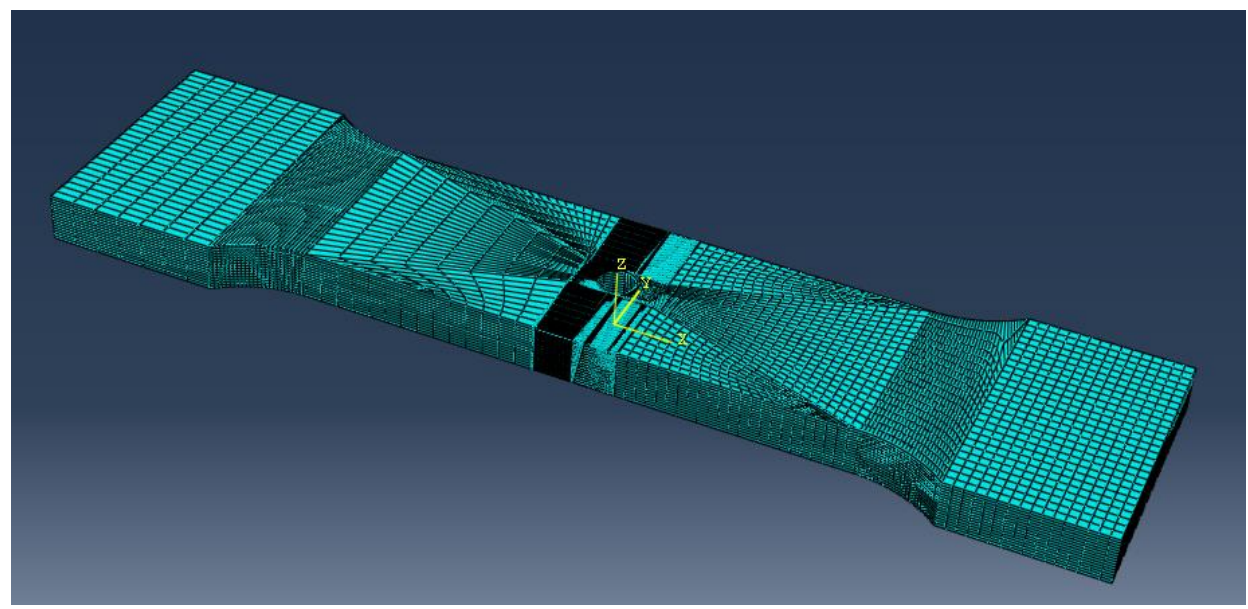

Figure 3: The mesh in finite element simulations

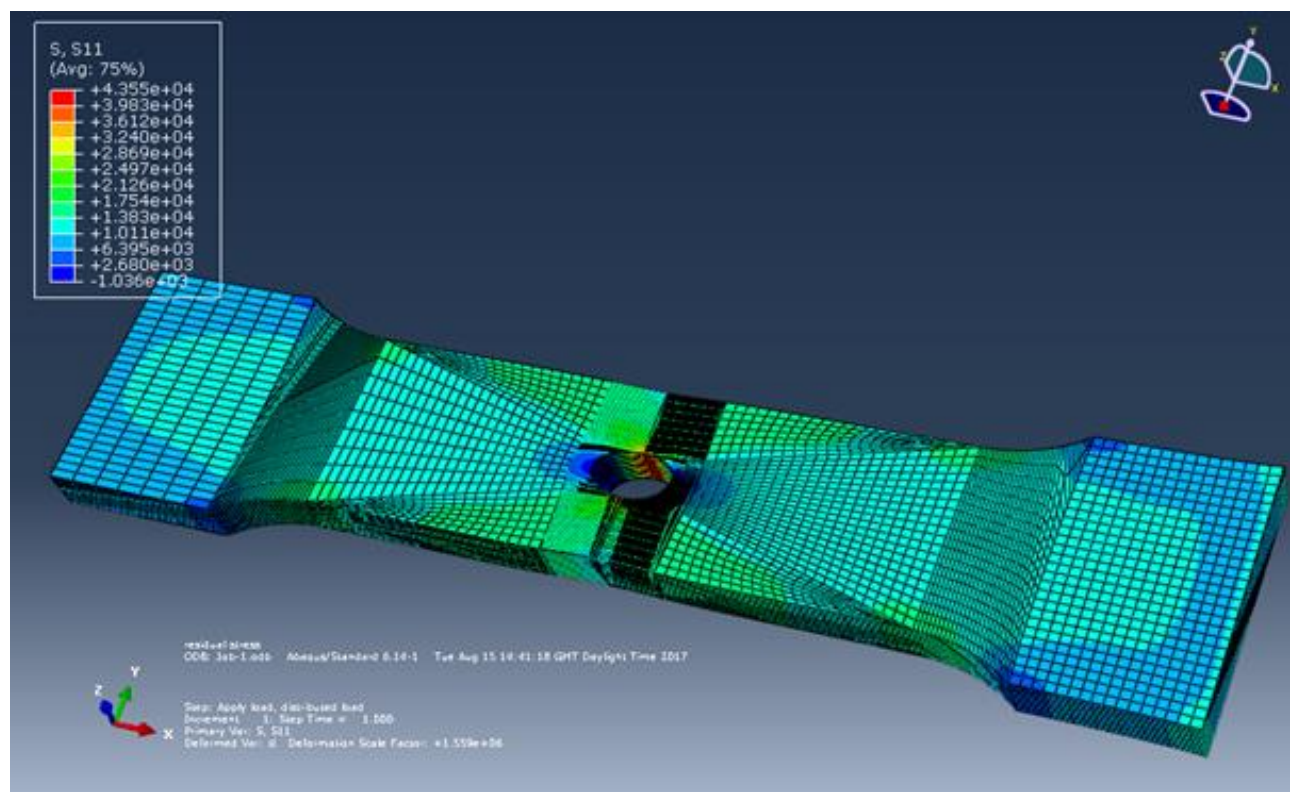

Figure 4: Stress distribution in experiment specimen 


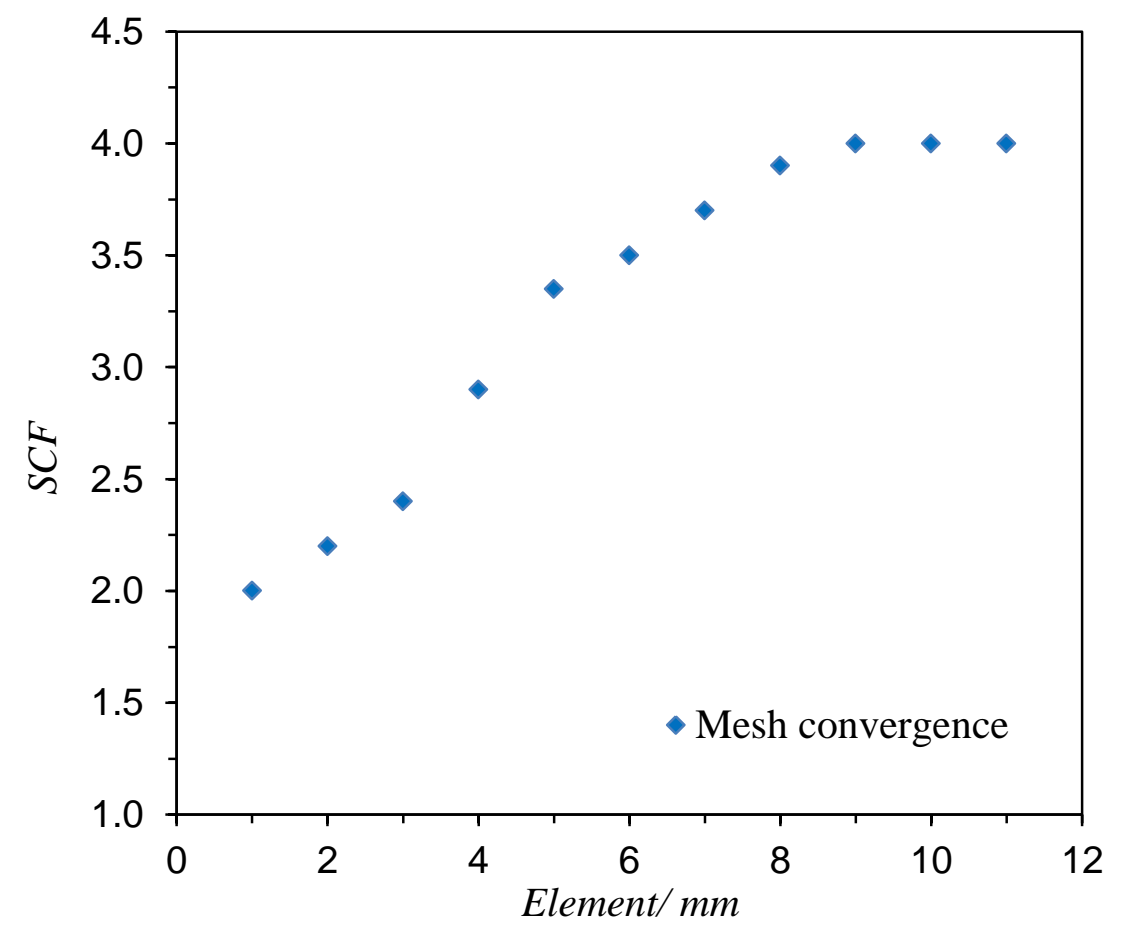

Figure 5: Mesh convergence for modelling

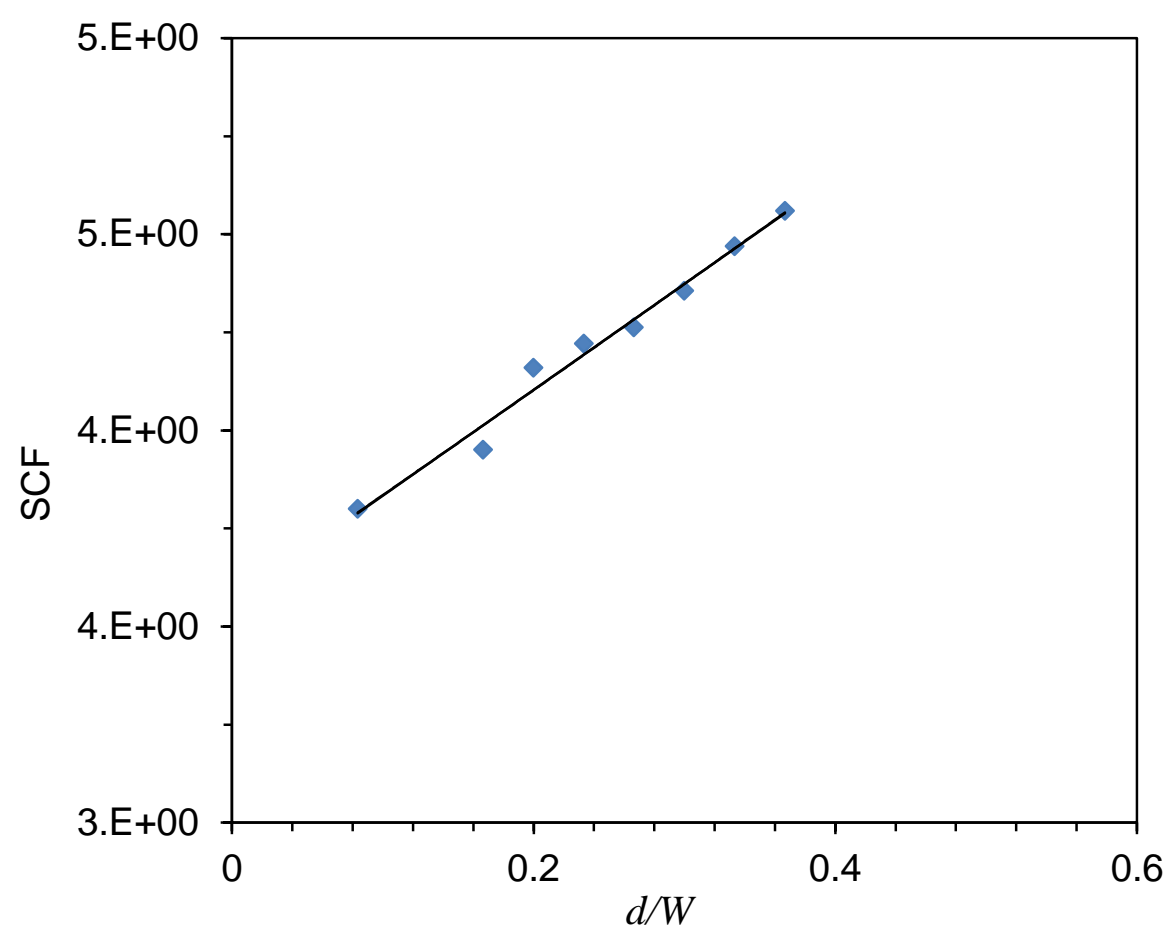

Figure 6: Stress concentration factor variation against normalised hole diameter 


\subsection{Partial surface shot peening details}

A shot peening technique, using which the surface is impacted with millions of small metallic or ceramic spheres, was used to introduce compressive residual stresses on the outer surface of specimens. There are various factors which influence the level of residual stresses due to shot peening, such as shot hardness, shot size and peening intensity [21][22][23][24]. In this study, a dual peening process was used to introduce partial peening areas on specimens. The dual peening process provides uniform compressive residual stresses on the peened surface by using smaller shot and lower intensity to drive the peaks into valleys which are left from the first peening process. The dual peening enhances fatigue strength of the material [25]. Table 3 shows the dual peening process details used in this study. The shots used were made of Cast Steel shot in both processes, with the media diameters being $1.9812 \mathrm{~mm}$ and 0.5842 $\mathrm{mm}$ for the first and second operations, respectively. The media flow rates were $8 \mathrm{~kg} / \mathrm{min}$ and $6 \mathrm{~kg} / \mathrm{min}$ for the first and second operations, respectively. The nozzle stood at a distance of $150 \mathrm{~mm}$ from the test specimens at a $90^{\circ}$ angle.

Table 3: Shot peening process details

\begin{tabular}{|l|c|c|}
\hline \multicolumn{1}{|c|}{ Operation details } & $\begin{array}{c}\text { S780H Shot Peening (1st } \\
\text { Operation) }\end{array}$ & $\begin{array}{c}\text { S780H Shot Peening (2nd } \\
\text { Operation) }\end{array}$ \\
\hline Media Type & Cast Steel Shot & Cast Steel Shot \\
\hline Media Diameter & $1.9812 \mathrm{~mm}$ & $0.5842 \mathrm{~mm}$ \\
\hline Media Mass & $32.00414 \mathrm{mg}$ & $0.82055 \mathrm{mg}$ \\
\hline Media Particles per 100g & 3,125 & $6 \mathrm{~kg} / \mathrm{min}$ \\
\hline Media Flow Rate & $8 \mathrm{~kg} / \mathrm{min}$ & $150 \mathrm{~mm}$ \\
\hline Nozzle Stand off & $150 \mathrm{~mm}$ & $90^{\circ}$ \\
\hline Peening Angle & $90^{\circ}$ & 121,869 \\
\hline
\end{tabular}

\subsection{Residual stress measurements}

An incremental hole drilling method was used to measure the residual stress profile in the partially shot peened specimens. The residual stress profile in the A10 specimen is shown here as an example. The residual stresses have been measured at different selected points to provide a distribution map in the specimen as shown in Figure 1. The residual stresses were 
measured along longitudinal and transverse directions, with respect to the loading axis. Figure 7 and Figure 8 show the residual stresses profiles for the A10 specimen in longitudinal and transverse directions, respectively. The maximum magnitude of compressive residual stress at the peened region was approximately $500 \mathrm{MPa}$ in the longitudinal direction and 550 $\mathrm{MPa}$ in the transverse direction. The compressive residual stress depth was $(0.8-1 \mathrm{~mm})$. The maximum tensile residual stresses value measured in this specimen is $150 \mathrm{MPa}$ in longitudinal and transverse directions and is located in the area between the peened regions.

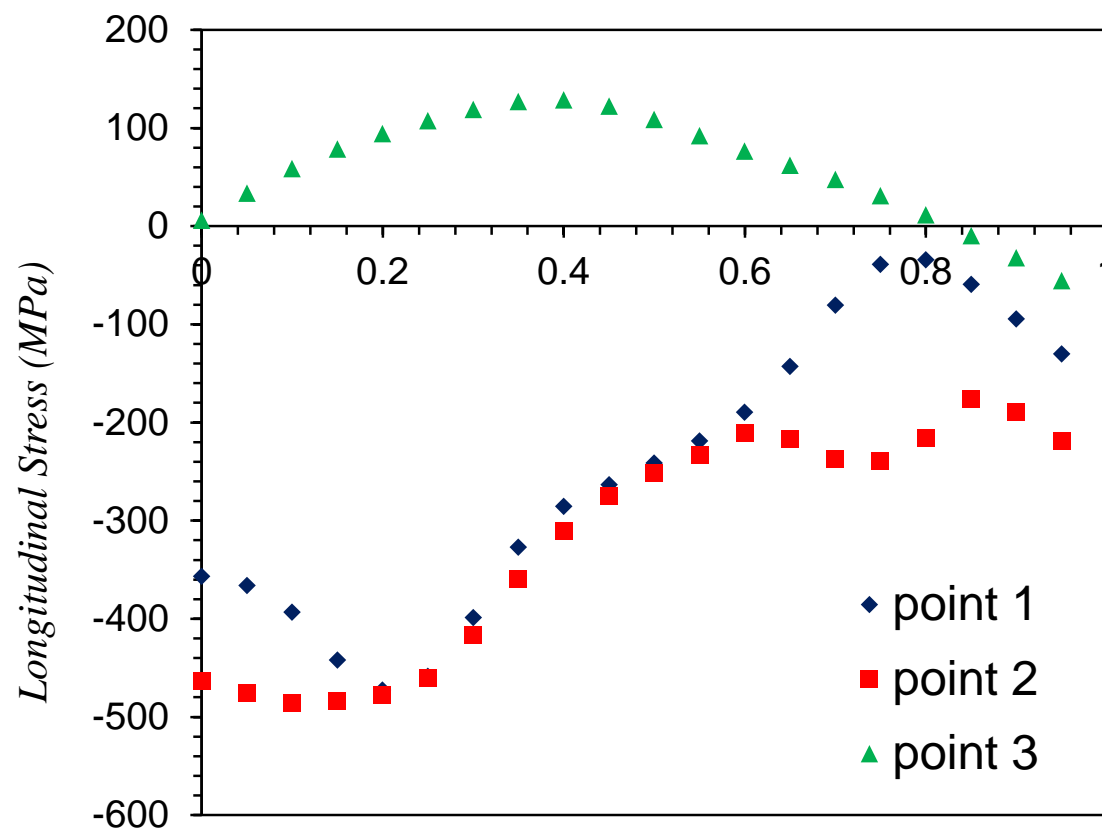

Overall depth $(\mathrm{mm})$

Figure 7: Residual stress profile in longitudinal direction 


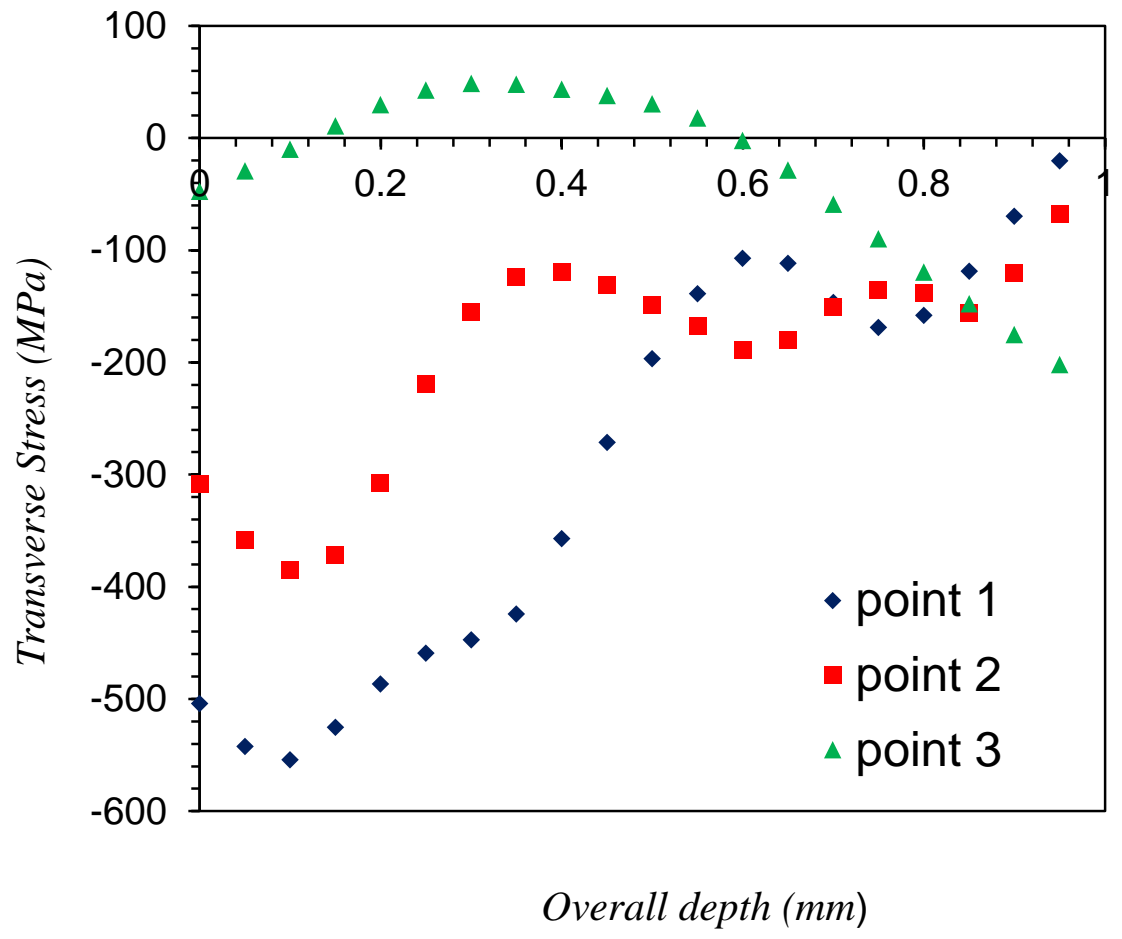

Figure 8: Residual stress profile in transverse direction

\subsection{Fatigue crack growth testing}

Tension-Tension fatigue tests were carried out in ambient temperature of $25^{\circ}, 3 \mathrm{~Hz}$ frequency, maximum load of $90 \mathrm{kN}$ and load ratio of $R=0.1$. An Instron machine equipped with a $250 \mathrm{kN}$ load cell was used to perform these tests. The pre-cracking has been done for tension fatigue specimens to reduce the machining effects at the initial notch tip. The precracking started with the maximum load of $120 \mathrm{kN}$ which was gradually reduced to $90 \mathrm{kN}$ towards the end of pre-cracking. A constant $R$-ratio of 0.1 was maintained during the prefatigue cracking process. The sinusoidal wave loads were implemented in the wave matrix software provided by Instron and applied to the samples. The implemented test method in the software contains three steps for continuous fatigue crack propagation. These three-steps are described as follows:

a) Step 1: The specimen is ramped up to the minimum load (within 2 seconds).

b) Step 2: Applied sinusoidal load between the maximum load and the minimum load.

c) Step 3: The test was ramped down to zero load at the end of the test. 


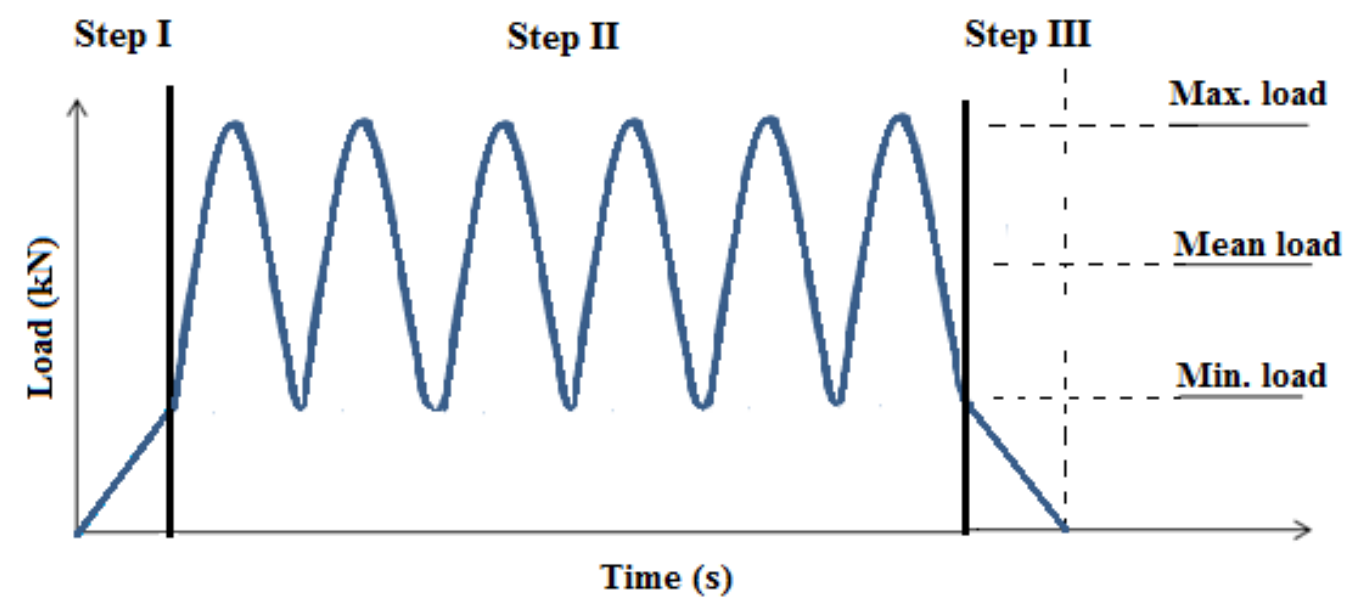

Figure 9: Demonstration of the test method implemented in the wave matrix

\subsection{Crack growth monitoring and fatigue crack growth rate calculations}

The crack length was monitored during fatigue tests using a StreamPix 5 digital camera. The crack length data were recorded and collected manually in conjunction with the cycle numbers. The stress intensity factor range $\Delta K$ for this specimen geometry was calculated according to ASTM E647 by using the following equations.

$\alpha=\frac{2 a}{W}$

Equation 3

$\Delta K=\frac{\Delta P}{B} \sqrt{\frac{\pi \alpha}{2 W} \sec \frac{\pi \alpha}{2}}$

Equation 4

In Equation 3 and Equation 4, $a$ is the total crack length, $W$ is the total width of specimen, $B$ is the specimen thickness and $\Delta P$ is the difference between the maximum load $P_{\max }$ and minimum load $P_{\text {min }}$.

The fatigue crack growth rate, which is the crack extension rate due to fatigue loading, can be represented by the average crack extension per cycle. The seven-point incremental polynomial technique, which is suitable for a test performed continuously and smoothly, has been used to calculate the fatigue crack growth rate in accordance with ASTM E647. 
$a_{i}=b_{o}+b_{1}\left(\frac{N_{i}-C_{1}}{C_{2}}\right)+b_{2}\left(\frac{N_{i}-C_{1}}{C_{2}}\right)^{2}$

Equation 5

where

$$
\begin{aligned}
& -1 \leq\left(\frac{N_{i}-C_{1}}{C_{2}}\right) \leq+1 \\
& \left(\frac{d a}{d N}\right)_{a i}=\left(b_{1}\right) /\left(C_{2}\right)+2 b_{2}\left(N_{i}-C_{1}\right) / C_{2}^{2}
\end{aligned}
$$

Equation 6

Equation 7

\section{Experimental results from fatigue crack growth tests}

The fatigue crack growth data from each test were analysed using the equations and procedure detailed in section 2 . The fatigue crack growth rates, $d a / d N$, for each test are correlated with the stress intensity factor range $\Delta K$ and the results are shown in Figure 10, Figure 12, Figure 13 and Figure 14 for the A10, A20, A30 and A60 specimens, respectively and the collected data from various tests are compared with each other in Figure 17. Note that the loading conditions and cyclic frequency were kept the same in all fatigue crack growth tests performed in this study.

\subsection{Fatigue test results for the A10 specimen}

Specimen A10, which contains a peening area $1.75 \mathrm{~mm}$ distant from the head of the crack-tip, was tested under tension-tension fatigue loading condition. It has been observed during the test that fatigue crack growth became retarded when the fatigue crack reached the peened region in the sample. The fatigue crack growth rate versus stress intensity factor range in the $\log -\log$ scale for the A10 specimen in Figure 11 show that there is deceleration in the early stage of the test and this is interpreted as fatigue crack retardation. Except for the retardation in the early stage in the fatigue crack growth test, it can be seen that there is a relatively linear relation between fatigue crack growth rate $d a / d N$ and stress intensity factor range $\Delta K$ for the rest of the test. As shown Figure 11, the retardation due to the beneficial compressive residual stress in the peened area occurred in this specimen at the beginning of the test. 


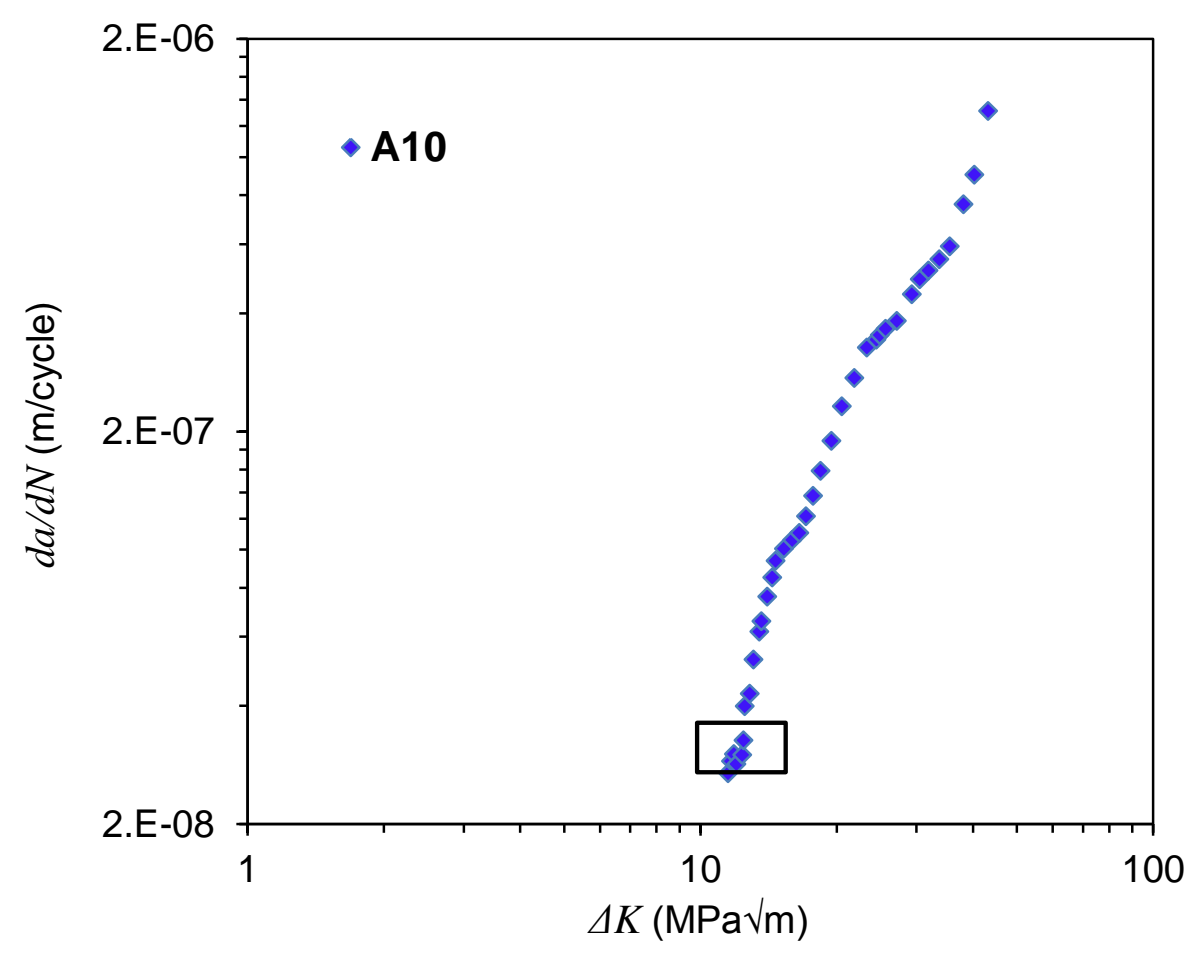

Figure 10: Fatigue crack growth results for A10

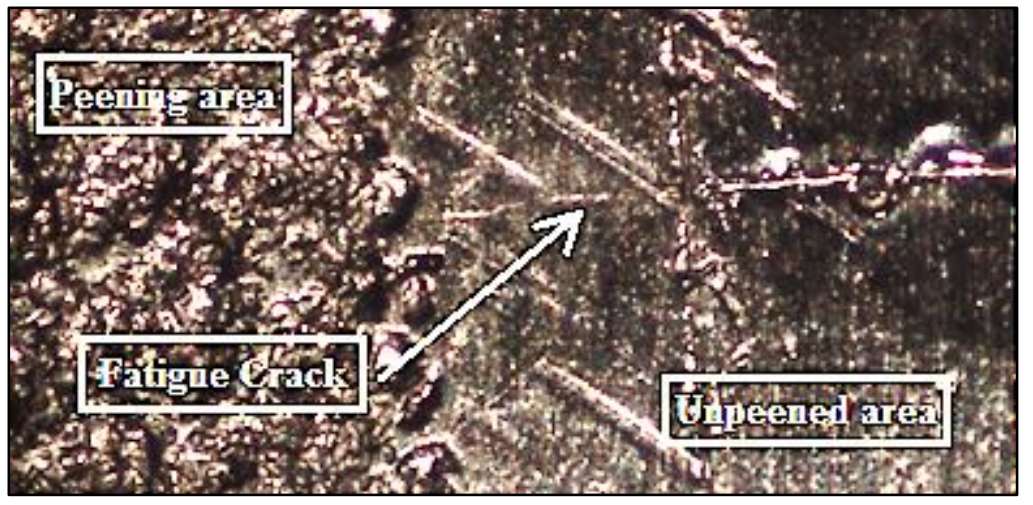

Figure 11: Illustration of fatigue crack growth retardation in the peened area

\subsection{Fatigue test results for the A20 specimen}

Specimen A20 which has a peened area $6.5 \mathrm{~mm}$ distant from the head of the notch tip was tested under fatigue loading conditions and the results are shown in Figure 12. It can be observed in this figure that compressive residual stresses induced as a result of shot peening have decelerated the crack growth once the crack had reached the peened region. Further seen in Figure 12 is that the fatigue crack growth rate shows an increasing trend with an increase in $\Delta K$ after the crack has entered the peened area. 


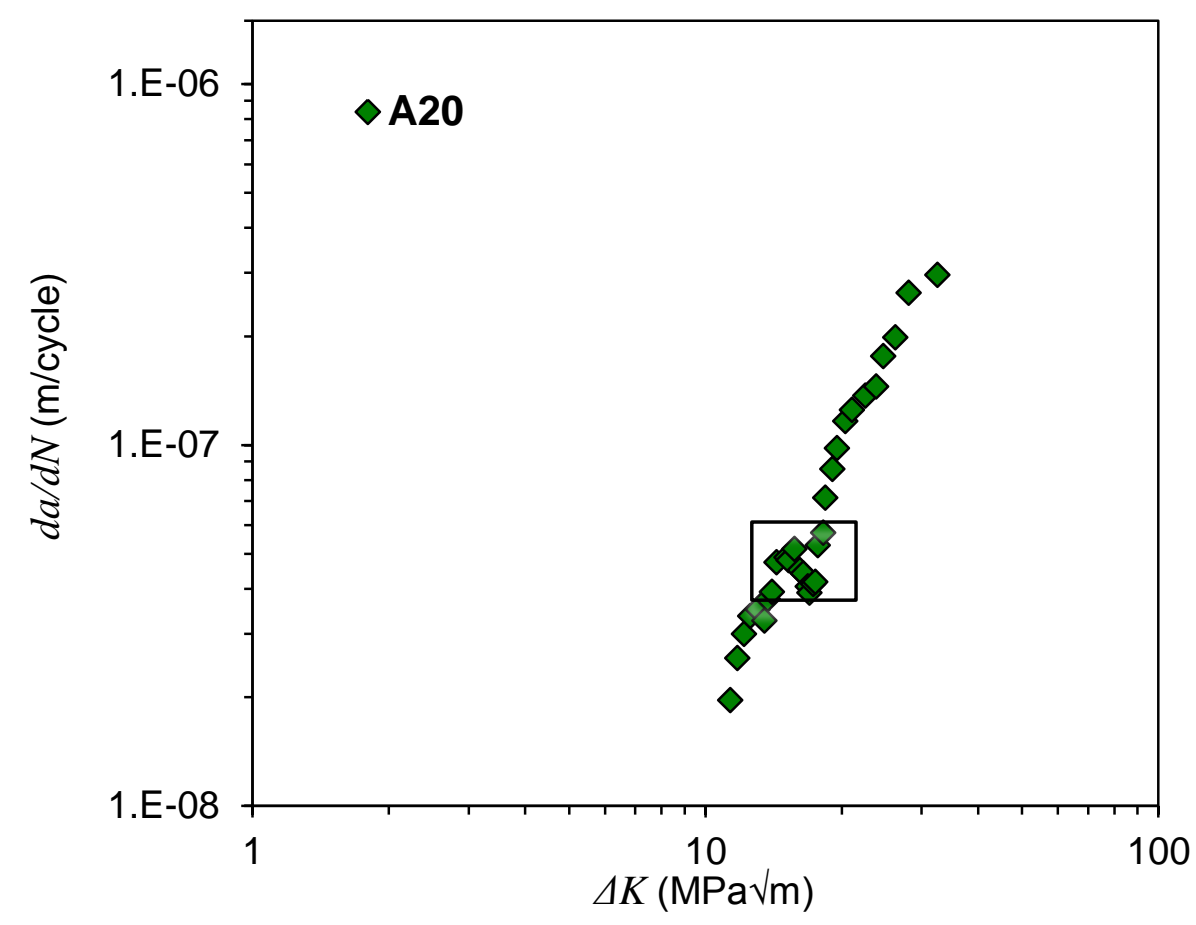

Figure 12: Fatigue crack growth results for A20

\subsection{Fatigue test results for A30 specimen}

The fatigue crack growth results obtained from A30-1 and A30-2 specimens are presented in Figure 13. It can be seen in this figure that the fatigue crack growth rate decreases gradually when the fatigue crack reaches the peened area, which is a behaviour consistent with what was observed in the A20 and A10 specimens. Similarly this reduction in the fatigue crack growth trend is thought to be due to compressive residual stresses in the loading direction. 


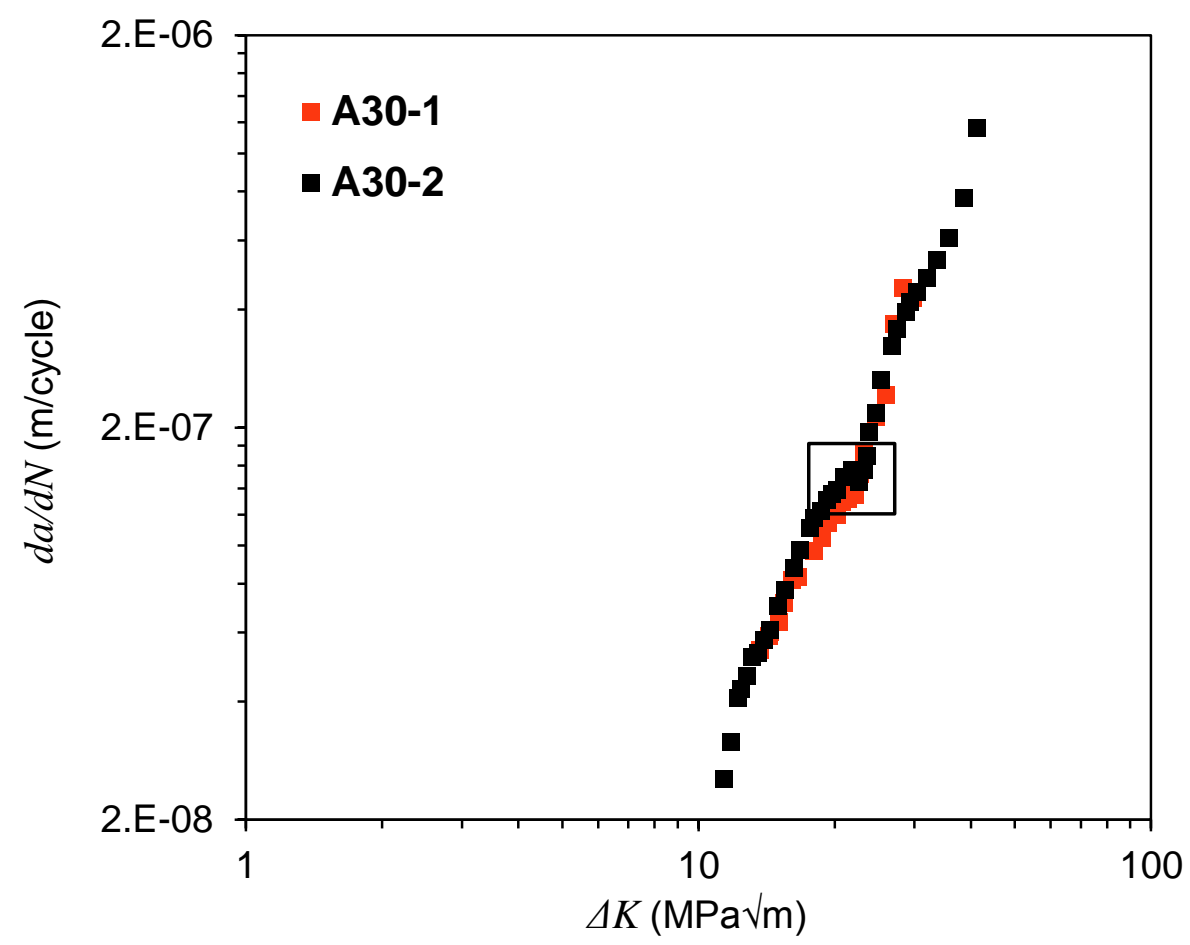

Figure 13: Fatigue crack growth results for A30

\subsection{Fatigue test results for the A60 specimen}

Fatigue crack growth test results from the tests performed on the A60 unpeened specimen are shown in Figure 14. The fatigue test results obtained from the unpeened specimen show that there is a smooth increase in fatigue crack growth rates with an increase in the stress intensity factor range when the data are plotted in log-log axes, with no evidence of crack retardation (reduction in fatigue crack growth rate) in this sample. The results from the A60 unpeened specimen are compared with the data from the open literature on 50D steel with a yield strength of $370 \mathrm{MPa}$, tested under load ratio (0.1) [26] and SE702 with a yield strength of 780 $\mathrm{MPa}[27]$ tested under load ratio (0.7) in Figure 14. It can be seen in this figure that the fatigue crack growth versus stress intensity range data for all materials exhibit similar trends. The Optim 700QL steel appears to have better resistance to fatigue crack growth compared to SE702 steel and is less fatigue resistant compared to 50D steel. 


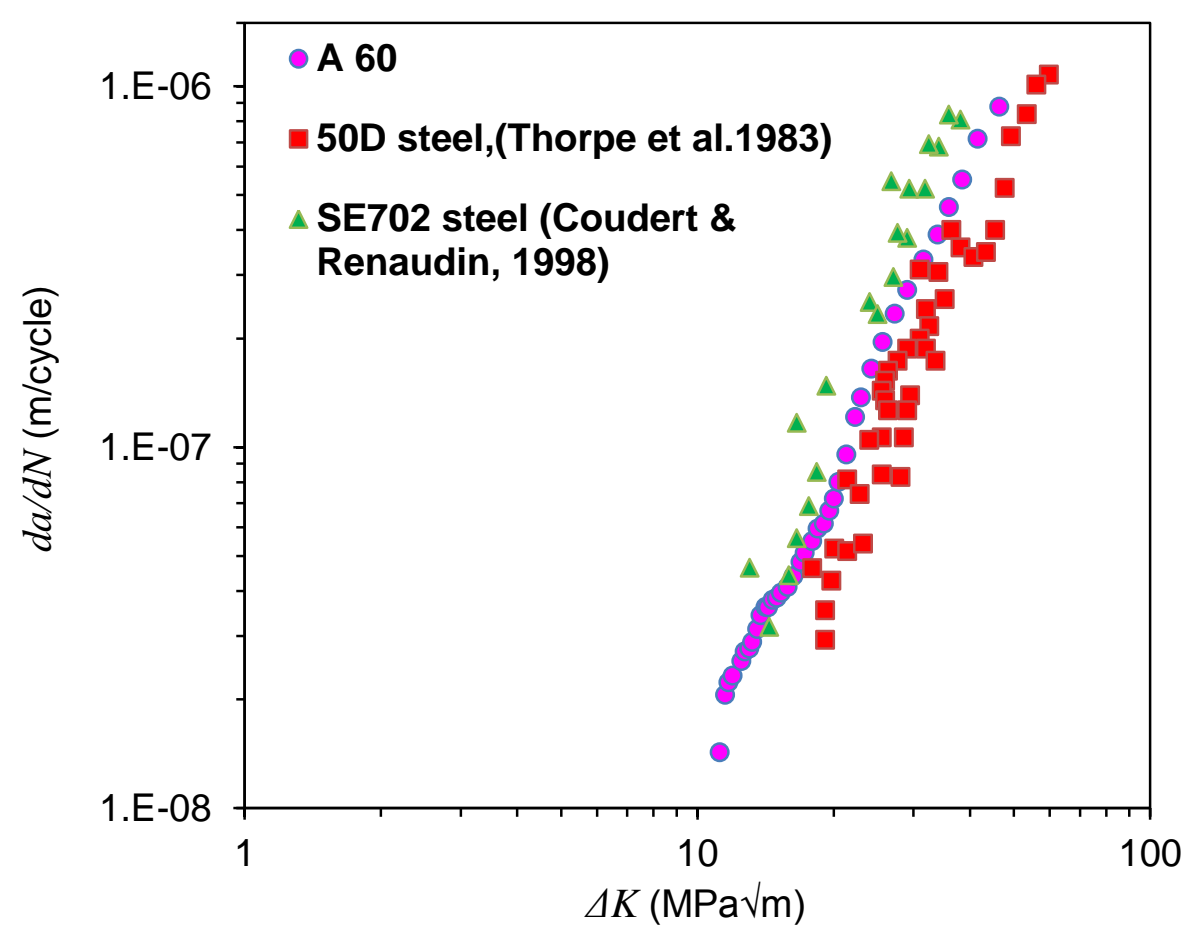

Figure 14: Fatigue crack growth rate for A60

\section{Fractography}

All fatigue crack growth specimens were soaked in liquid nitrogen for 30 minutes posttesting and then broken open by loading them under tension on an Instron machine. The fracture surface of all fatigue crack growth specimens were examined after being broken open and those for the A10 and A30-1 specimens are shown in Figure 15 and Figure 16, respectively, as examples. These pictures show that distinctive regions can be clearly observed on the fracture surface of the broken open specimens. First of all, the pre-cracking area, where the fatigue load was reduced from $120 \mathrm{kN}$ to $90 \mathrm{kN}$, leads to generate beachmarks on the fracture surfaces, which can be observed and identified on the fracture surface. The next region observed on the fracture surface is the fatigue propagation region which is clearly demarcated on the fracture surface. Also, it can be clearly seen that a transition area from fatigue to fast fracture is observed towards the end of the tests where the stress intensity factor approaches its critical $K_{I C}$ value in the accelerating fatigue crack growth region. Crack tunnelling is also apparent at the end of the transition region which demonstrates a faster crack growth at the mid-thickness of the specimen, compared to the outer sides of the specimen. This transition region is followed by a fast fracture region at the end of the fracture surface which appears to be shinier than the rest of the fracture surface. 
Also observed in Figure 15 and Figure 16 is that there are shiny edges in both the A10 and A30-1 specimens which happened to be in the shot peened area. Knowing that shot peening induces compressive residual stresses on the outer surface of the specimens, which subsequently retard the fatigue crack growth, the force-balance characteristic of residual stress leads to a tensile residual stress field in the mid-thickness of the test specimens. The tensile residual stress forces the fatigue crack to grow faster at the mid-thickness of the specimen and retarded at the outer surface of the specimen, which leads to a more severe crack tunnelling in these partially surface shot peened specimens as seen Figure 15 and Figure 16. This implies that when an optical technique is used to monitor the crack growth on the outer surface of partially peened specimens, some inaccuracies might be encountered in fatigue crack growth measurements. This is due to crack tunnelling, and hence a greater difference between the crack growth at the mid-thickness of the sample and the extent of the crack extension measured using a camera at the outer surface of the specimen.

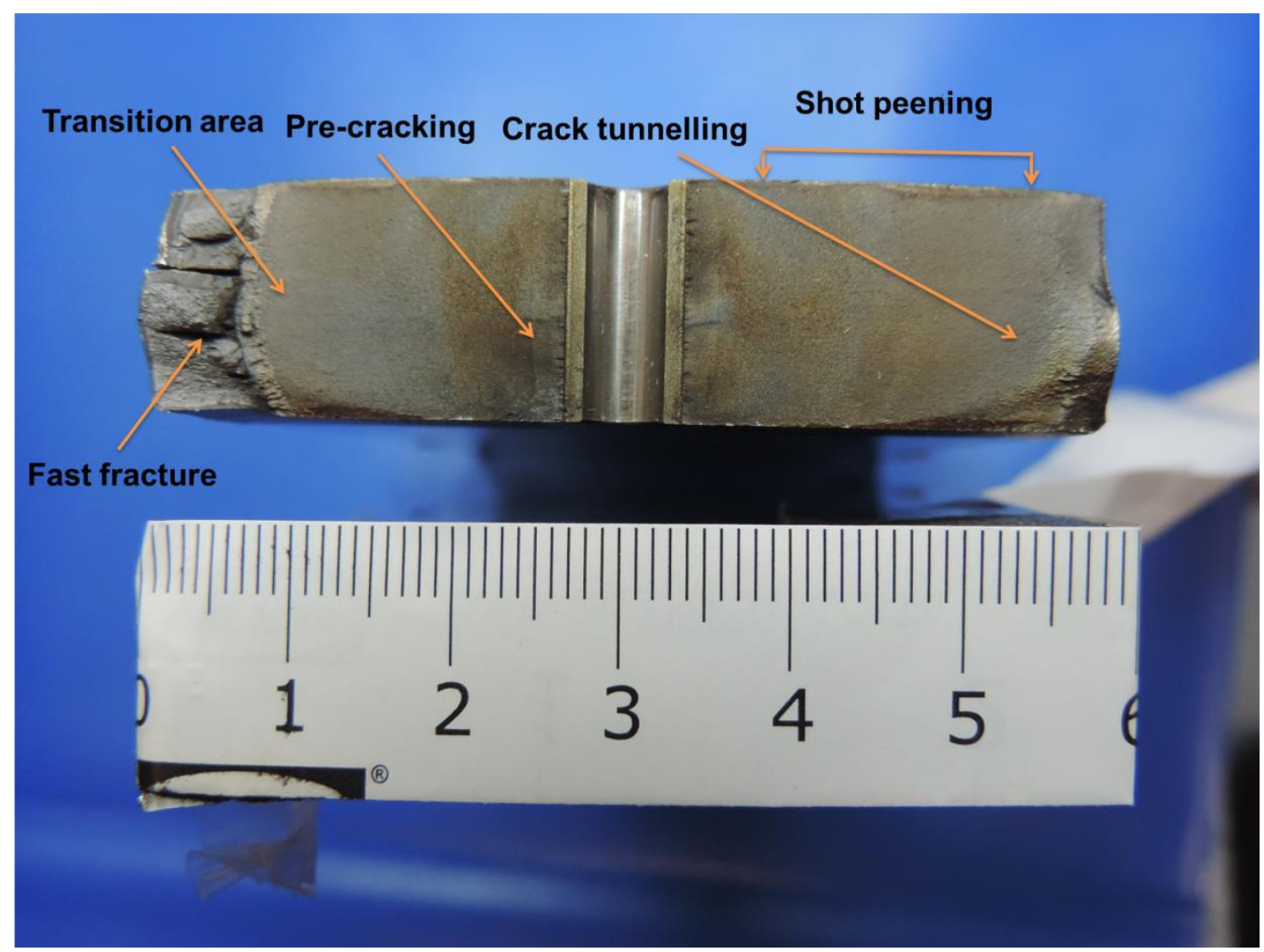

Figure 15: Fracture surface for A10 specimen 


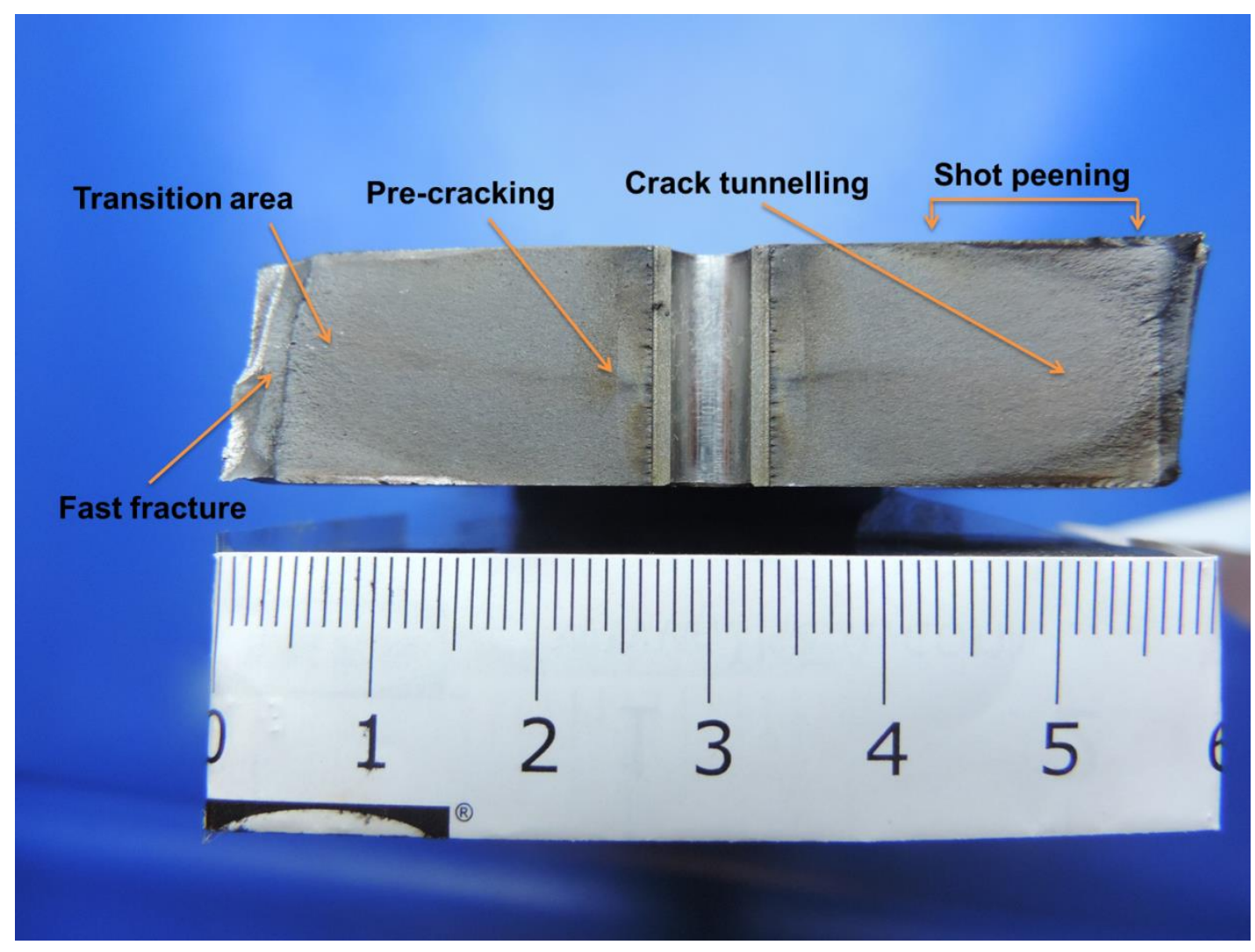

Figure 16: Fracture surface for A30 specimen

\section{Discussion}

The fatigue crack growth results from the tests performed in this study are collectively shown and compared in Figure 17. This figure clearly demonstrates that partial surface shot peening significantly influences the fatigue crack growth behaviour of the material. The results of the A60 test data show that the fatigue crack growth rate linearly increased with an increase in the stress intensity factor range when the data were plotted in log-log axes. This behaviour is known as the Paris law and is typically observed in all fatigue crack growth tests [28]. It can be seen in Figure 17 that a reduction in fatigue crack growth rates was observed in all specimens, which were partially peened, with the A10, A20 and A30 specimens showing a retardation at lower, intermediate and higher $\Delta K$ values, respectively. This shows that the stress intensity factor range at which the fatigue crack retardation occurs increases as the area of the unpeened region increases on the surface of the examined specimens. The presented test results have been divided into three regions in Figure 17 for clarity. At lower range of stress intensity factor (region I), it can be observed in Figure 17 that there is no noticeable difference in the fatigue crack growth results, though the fatigue crack in A10 specimen is 
already entered the peened region and shows a slight drop in FCG rate. The most interesting region is the intermediate stress intensity factor range of $15-30 \mathrm{MPa} \sqrt{\mathrm{m}}$, which is referred to as region II in Figure 17, in which the partial peening area has significantly affected the fatigue crack growth rates in all of the partially peened specimens. The comparison of the test results from A10, A20 and A30 specimens in region II shows that the highest and lowest fatigue crack growth trends were observed in A10 and A60 (i.e. unpeened) specimens, respectively, with the test data from A20 and A30 samples falling in between and close to each other. It can be seen that within region II stress intensity factor range for a given value of $\Delta K$, the fatigue crack growth rate in the A10 partially peened specimen is around twice faster than the unpeened sample. This indicates that although the fatigue crack growth is retarded as a result of partial surface shot peening, the fatigue crack growth trend shifts up simultaneously due to the formation of tensile residual stresses at the mid-thickness of the specimen. Further observed in Figure 17 is that the extent of FCG rate reduction in A20 specimen is greater than those of seen in A10 and A30-1 and A30-2 specimens. The fatigue test results confirm that the extent of tensile residual stresses increases as the size of the unpeened region decreases in the partially shot peened specimens. In other words, if surface shot peening is used to introduce compressive residual stresses in a component and subsequently reduce fatigue crack growth rates, a partially unpeened region can lead to a significant increase in the overall fatigue crack growth trends. Finally seen in Figure 17 is that in the highest stress intensity factor range of larger than $30 \mathrm{MPa} \sqrt{\mathrm{m}}$ (region III) similar fatigue crack growth trends can be observed in the unpeened and partially peened specimens. 


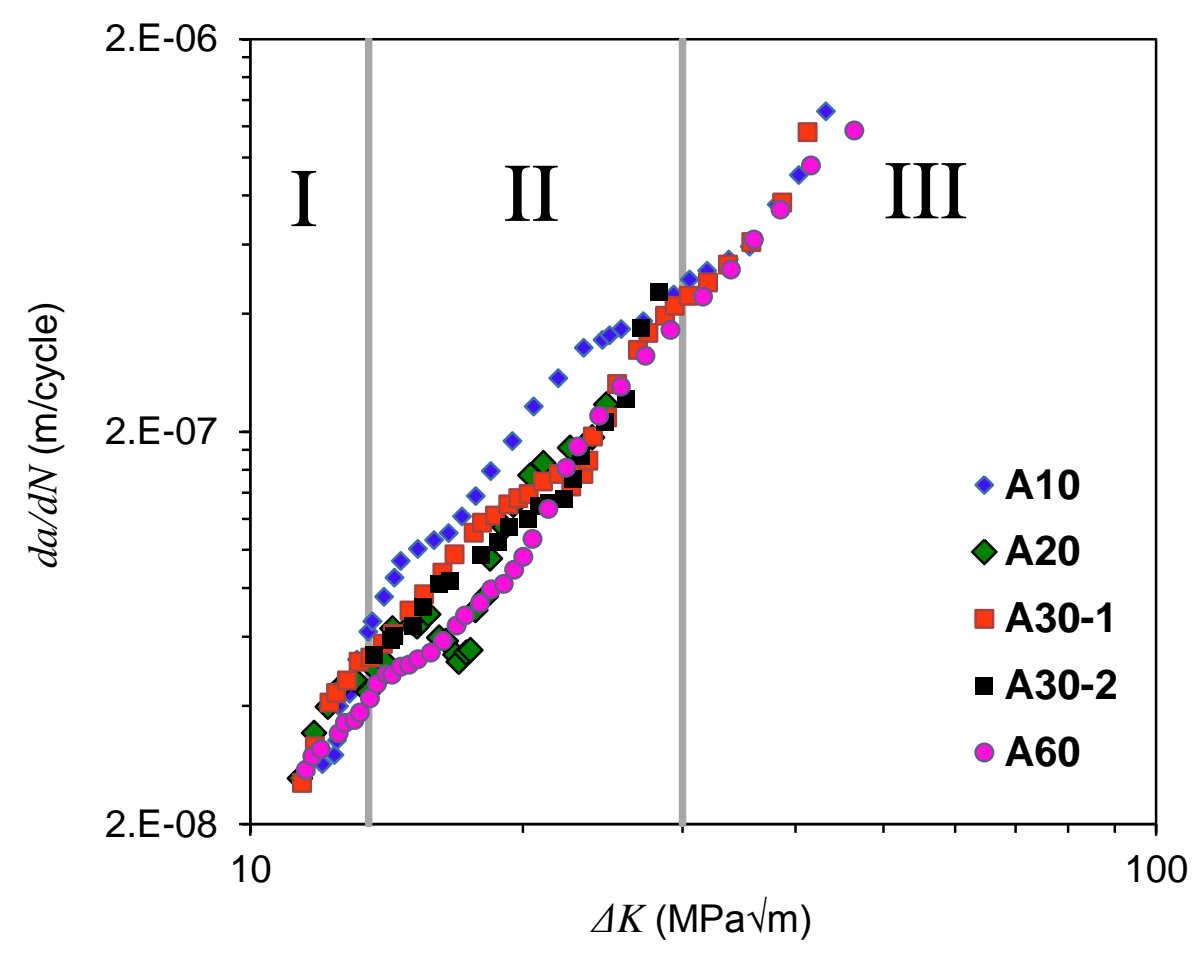

Figure 17: Comparison between different fatigue crack growth trends

\section{Conclusions}

Tension-Tension fatigue tests have been conducted on partially shot peened, high strength steel, dog-bone specimens. The investigation involved performing fatigue tests on specimens with three different extents of partial surface peening and also an additional test on an unpeened specimen. Based on limited testing the following preliminary qualitative conclusions have been drawn from this experimental study:

1- A reduction in fatigue crack growth rates is observed when the crack tip enters the peened region.

2- The stress intensity factor range at which the crack retardation occurs in partially peened specimens increases by increasing the extent of the unpeened region size from $10 \mathrm{~mm}$ to $20 \mathrm{~mm}$ and $30 \mathrm{~mm}$.

3- Although partial surface peening leads to crack retardation as a result of compressive residual stresses, due to the induced global tensile residual stresses in the material, higher fatigue crack growth trends are observed in the partially peened specimens compared to the unpeened sample. 
4- The highest fatigue crack growth trend is observed in the specimen with the smallest unpeened region size (A10).

5- For a given value of $\Delta K$, the fatigue crack growth rate in the A10 partially peened specimen is around twice as fast as the unpeened sample.

6- The fatigue crack retarded when reaching the peening area but it continues in the midthickness of the specimen, causing severe crack tunnelling.

In order to improve confidence in the above, further repeat tests need to be conducted.

\section{Acknowledgement}

This work has been supported by the University of Babylon-Ministry of Higher Education and Scientific Research of Iraq. Ali S. Al-Turaihi gratefully acknowledges this support. 


\section{References}

[1] A. Niku-Lari and IITT.France, "An overview of Shot Peening," Intl Conf Shot Peen. Blast Clean., pp. 1-25, 1996.

[2] L. Trško, M. Guagliano, O. Bokůvka, and F. Nový, "Fatigue life of AW 7075 aluminium alloy after severe shot peening treatment with different intensities," Procedia Eng., vol. 74, no. October, pp. 246-252, 2014.

[3] M. K. Kulekci and U. Esme, "Critical analysis of processes and apparatus for industrial surface peening technologies," Int. J. Adv. Manuf. Technol., vol. 74, no. 912, pp. 1551-1565, 2014.

[4] G. Donzella, R. Gerosa, C. Petrogalli, B. Rivolta, G. Silva, and M. Beretta, "Evaluation of the residual stresses induced by shot peening on some sintered steels," Procedia Eng., vol. 10, pp. 3399-3404, 2011.

[5] H. Yang, X. Wu, G. Cao, and Z. Yang, "Enhanced boronizing kinetics and high temperature wear resistance of $\mathrm{H} 13$ steel with boriding treatment assisted by air blast shot peening," Surf. Coatings Technol., vol. 307, pp. 506-516, 2016.

[6] J. Gan, D. Sun, Z. Wang, P. Luo, and W. Wu, "The effect of shot peening on fatigue life of Q345D T-welded joint,” J. Constr. Steel Res., vol. 126, pp. 74-82, 2016.

[7] B. Pyttel, I. Varfolomeyev, M. Luke, C. Berger, and D. Siegele, "FKM Guideline 'Fracture Mechanics Proof of Strength for Engineering Components' - Overview and Extension Topics," Weld. World, vol. 51, no. 5-6, pp. 85-93, 2013.

[8] E. Giannakis and G. Savaidis, "Fatigue assessment of high strength leaf springs based on the FKM guideline," Materwiss. Werksttech., vol. 47, no. 10, pp. 897-903, 2016.

[9] A. H. Mahmoudi, A. Ghasemi, G. H. Farrahi, and K. Sherafatnia, "A comprehensive experimental and numerical study on redistribution of residual stresses by shot peening," Mater. Des., vol. 90, pp. 478-487, 2016.

[10] F. Yang, Z. Chen, and S. A. Meguid, "Effect of initial surface finish on effectiveness of shot peening treatment using enhanced periodic cell model," Int. J. Mech. Mater. Des., vol. 11, no. 4, pp. 463-478, 2014. 
[11] K. Takahashi, H. Okada, and K. Ando, "Effects of shot peening on the torsional fatigue limit of high- strength steel containing an artificial surface defect," Int. J. Struct. Integr., vol. 3, no. 3, pp. 274-284, 2012.

[12] H. K. Akyildiz, M. K. Kulekci, and U. Esme, "Influence of shot peening parameters on high-cycle fatigue strength of steel produced by powder metallurgy process," Fatigue Fract. Eng. Mater. Struct., vol. 38, no. 10, pp. 1246-1254, 2015.

[13] T. Honda, M. Ramulu, and A. S. Kobayashi, "Fatigue of shot peened 7075-T7351 SENB specimen - A 3-D analysis," Fatigue Fract. Eng. Mater. Struct., vol. 29, no. 6, pp. 416-424, 2006.

[14] H. Ishigami, K. Matsui, Y. Jin, and K. Ando, "Study on stress, reflection and double shot peening to increase compressive residual stress," Fatigue Fract. Eng. Mater. Struct., vol. 23, no. 11, pp. 959-963, 2000.

[15] H. J. C. Voorwald, M. P. Silva, M. Y. P. Costa, and M. O. H. Cioffi, "Improvement in the fatigue strength of chromium electroplated AISI 4340 steel by shot peening," Fatigue Fract. Eng. Mater. Struct., vol. 32, no. 2, pp. 97-104, 2009.

[16] C. You, M. Achintha, K. A. Soady, N. Smyth, M. E. Fitzpatrick, and P. A. S. Reed, "Low cycle fatigue life prediction in shot-peened components of different geometriespart I: Residual stress relaxation,” Fatigue Fract. Eng. Mater. Struct.,vol. 40, pp. 761775, 2017.

[17] D. Závodská, M. Guagliano, O. Bokůvka, and L. Trško, "Fatigue Resistance of Low Alloy Steel after Shot Peening," Mater. Today Proc., vol. 3, no. 4, pp. 1220-1225, 2016.

[18] J. Billingham, J. V. Sharp, J. . Spurrier, and P. J. Kilgallon, "Review of the performance of high strength steels used offshore," Rev. Perform. high strength steels used offshore, pp. 6-8, 2003.

[19] U. Masteel UK limited B46 2HH coleshill, Vastaanottotodistus inspection certificate, vol. EN 10204-3. 2004.

[20] D. S. S. C. "Abaqus 6.13 Keywords Reference Manual” and U. 2013 Providence, RI, “Abaqus/CAE User's Manual: Version 6.5 Documentation.” pp. 1-19, 2013. 
[21] G. T. Robertson, "The effect of shot size on the residual stresses resulting from shot peening," Shot Peen. Mag., vol. 11, no. 3, p. 3, 1997.

[22] K. Toshal, J. Lu, B. Guelorget, and E. Nagashima, "Shot Peening and Grit Blasting Effects on Surface Integrity-," Icsp9 Shot Peen., pp. 400-405, 2005.

[23] H. Guechichi, L. Castex, and M. Benkhettab, "An Analytical Model to Relate Shot Peening Almen Intensity to Shot Velocity," Mech. Based Des. Struct. Mach., vol. 41, no. 1, pp. 79-99, 2013.

[24] a. T. Vielma, V. Llaneza, and F. J. Belzunce, "Effect of coverage and double peening treatments on the fatigue life of a quenched and tempered structural steel," Surf. Coatings Technol., vol. 249, pp. 75-83, 2014.

[25] L. Wagner, Shot Peening. Wiley VCH; 1 edition (6 Jun. 2003), 2003.

[26] T. W. Thorpe, P. M. Scott, A. Rance, and D. Silvester, "Corrosion fatigue of BS-436050d structural-steel in seawater," Int. J. Fatigue, vol. 5, no. 3, pp. 123-133, 1983.

[27] E. Coudert and C. Renaudin, "Variable amplitude corrosion fatigue behaviour and hydrogen embrittlement of high strength steels for offshore applications," Int. Offshore Polar Eng. Conf., vol. IV, pp. 116-122, 1998.

[28] T. L. Anderson, FRACTURE MECHANICS Fundamentals and Applications, vol. ISBN:97808, no. 1. 2004. 